\title{
Statistical Analysis of Bored Piles with Pile-Bottom Post Grouting
}

\author{
B.J. Li \& H.M. Zang \\ Limited Company of Shandong road and bridge group, Jinan, Shandong, China \\ G.H. Lv \\ Research Center of Geotechnical and Structural Engineering, Shandong University, Jinan, China
}

\begin{abstract}
The statistics of cement consumption, bearing capacity, and settlements for pile-head and piletoe are obtained by using the comparison of over 600 piles with or without grouting. The statistical results show that post grouting technique is most used in gravel and pebble stratum (taking up 67.8\%), followed by silty sand (taking up 20.3\%), and can also be used in silt and clay and bedrock. The post grouting technique is used in bedrock to solidify rock mass and sediment. By regression analysis of piles in gravel and pebble stratum or silt, the cement consumption is found to be linear with the square of pile diameter. Enhancement coefficient of post grouting pile's bearing capacity is 1.25 in silt and clay, 1.31 in silty sand, 1.46 in gravel and pebble stratum, and 1.16 in bedrock, respectively. For piles with the same diameter, the improvement of bearing capacity in gravel and pebble stratum is the biggest. By post grouting, the settlements of pile-head and pile-toe can be reduced by $24 \% \sim 37 \%$ and $49 \% \sim 78 \%$, respectively.

KEYWORD: bored pile; sediment; mudcake; post grouting; statistical analysis
\end{abstract}

\section{INTRODUCTION}

Cast-in-situ bored piles have been worldwidely used as the foundations of heavy-load structures because of their high bearing capacity, relatively low cost and easy length adjustments during the installation. However, the existence of mudcake and sediment of bored cast-in-situ pile will reduce single-pile bearing capacity and increase pile settlement (Zhang et al. 2009). A majority of previous studies (Kusakabe et al. 1994; Thompson 1996; Fang et al. 2014; Zhang and Zhang, 2012) have been conducted to estimate the behavior of axially loaded pile with postgrouting. However, due to the presence of uncertainties, errors inevitably arise with the estimations. It can be found in the engineering projects that the effectiveness of pile-bottom post grouting correlated not only with the bearing layer but also with many other factors, such as pile diameter, pile length, subsoil condition, filling coefficient of concrete, curing age, sediment, and mudcake. So it is limited to analyze the grouting effect just by several piles. We have collected and compared over 600 piles with or without grouting, and obtain the statistics of cement consumption, bearing capacity, and pile-head and pile-toe settlements by static load test so as to guide the engineering practice and theory research.

\section{STATISTICAL METHODS}

The statistical methods used. If the sample size $n \leq 30$, its average can be computed by:

$$
\bar{X}=\sqrt[n]{X_{1} X_{2} \cdots X_{n}}
$$

Taking the logarithm on both side of the following equation, the value of $\bar{X}$ can be obtained.

$\lg \bar{X}=\frac{1}{n}\left(\lg X_{1}+\lg X_{2}+\cdots \cdots+\lg X_{n}\right)$

If the sample size $n>30$, its average can be computed by:

$$
\bar{X}=\frac{\sum_{i=1}^{n} X_{i}}{n}
$$

\section{STATISTICS OF BEARING LAYERS}

The distribution of bearing layers of grouted bored piles is summarized in Table 1 and Fig.1. 
Table 1 Distribution of bearing layers

\begin{tabular}{ccccc}
\hline $\begin{array}{c}\text { Bearing } \\
\text { layer }\end{array}$ & $\begin{array}{c}\text { Silt and } \\
\text { clay }\end{array}$ & $\begin{array}{c}\text { Silty } \\
\text { sand }\end{array}$ & $\begin{array}{c}\text { Gravel and } \\
\text { pebble }\end{array}$ & Bedrock \\
\hline $\begin{array}{c}\text { Number of } \\
\text { piles }\end{array}$ & 43 & 122 & 408 & 29 \\
Percentage & $7.1 \%$ & $20.3 \%$ & $67.8 \%$ & $4.8 \%$ \\
\hline
\end{tabular}

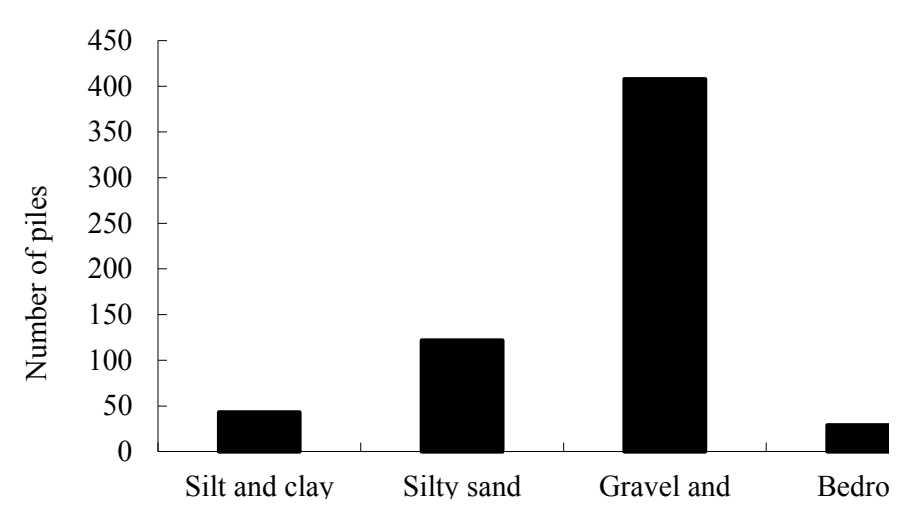

Fig.1 Distribution of bearing layers

Post grouting technique is most used in gravel and pebble stratum (taking up 67.8\%), followed by silty sand (taking up 20.3\%), and it can be used in silt and clay and bedrock as well. These data indicate that post grouting technique is more appropriate for cohesionless soil.

\section{STATISTICS OF CEMENT CONSUMPTION}

The statistics of cement consumption of grouted bored piles are listed in Table 2 and Fig.2. The results show that the cement consumption is in the range of 2 to 6 tons. It takes up 60.28 percent that the piles with cement consumption of 1 to 3 tons, which suggests the proper cement consumption of grouted bored pile during construction.

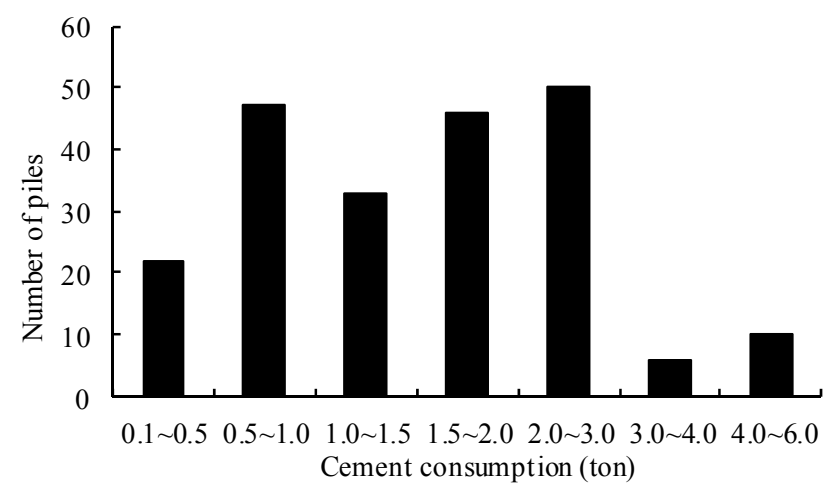

Fig.2 Statistics of cement consumption

Table 2 Statistics of cement consumption

\begin{tabular}{cccccccc}
\hline Cement consumption (ton) & $0.1 \sim 0.5$ & $0.5 \sim 1.0$ & $1.0 \sim 1.5$ & $1.5 \sim 2.0$ & $2.0 \sim 3.0$ & $3.0 \sim 4.0$ & $4.0 \sim 6.0$ \\
\hline Number of piles & 22 & 47 & 33 & 46 & 50 & 6 & 10 \\
percentage & $10.28 \%$ & $21.96 \%$ & $15.42 \%$ & $21.50 \%$ & $23.36 \%$ & $2.80 \%$ & $4.67 \%$ \\
\hline
\end{tabular}

Table 3 Statistics of cement consumption of piles with different diameters in various bearing layers (ton)

\begin{tabular}{|c|c|c|c|c|c|}
\hline Diameter & 600 & 800 & 900 & 1000 & $>1000$ \\
\hline \multicolumn{6}{|l|}{ Bearing layer } \\
\hline Gravel and pebble & 1.77 & 1.81 & 2.06 & 2.50 & 3.53 \\
\hline Silty sand & 1.05 & 1.61 & 1.91 & 2.35 & 2.75 \\
\hline
\end{tabular}

The cement consumption fluctuates mainly with bearing layers and pile diameters. And the statistics of cement consumption of piles with different diameters in various bearing layers are listed in Table 3 and Fig.3. The results show that the cement con-

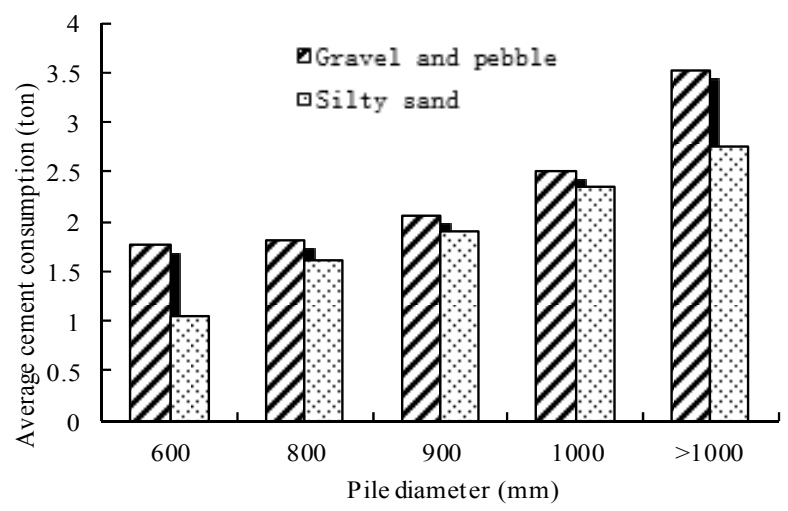

Fig.3 Statistics of cement consumption of piles with different diameters in various bearing layers sumption grows with the increase of pile diameter. Under a given diameter, the cement consumption of pile in gravel and pebble is obviously larger than that in silty sand, as the porosity is larger in gravel and pebble.

Fig.4 and Fig.5 show the regression curve of cement consumption versus pile diameter. The empirical formula of cement consumption by pile diameter in gravel and silty sand can be expressed as follows. 


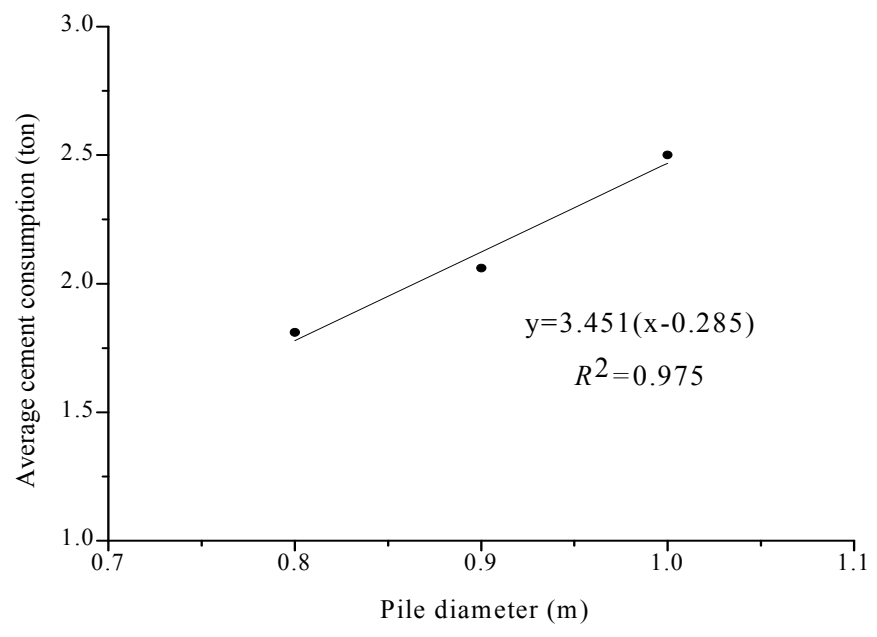

Fig.4 Relationship between cement consumption and pile diameter in gravel and pebble

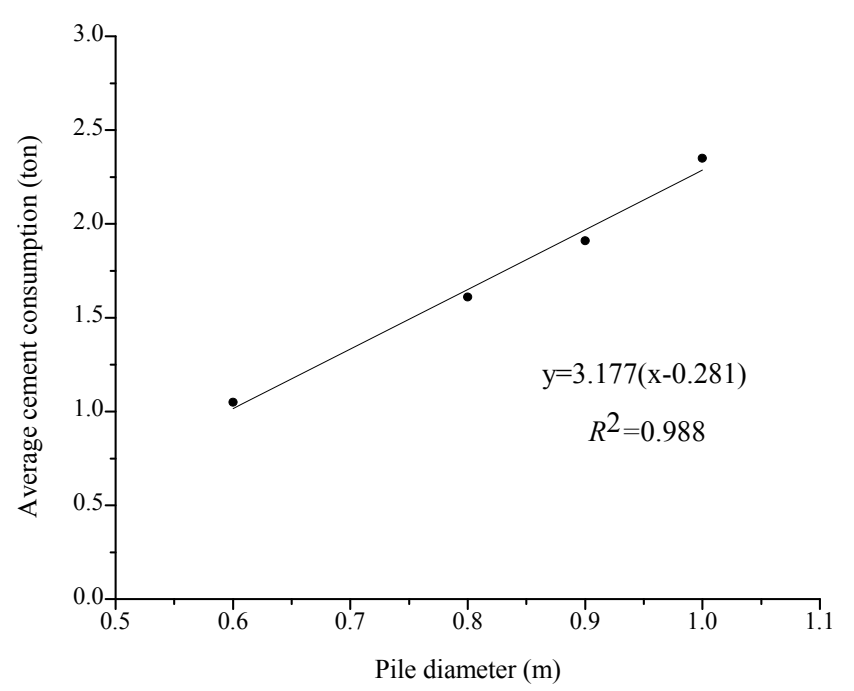

Fig.5 Relationship between cement consumption and pile diameter in silty sand

The cement consumption of a single-pile in gravel and pebble can be computed by:

$Q=3.451(D-0.285)$

The cement consumption of a single pile in silty sand is:

$Q=3.177(D-0.281)$

Where $Q$ is the cement consumption, and $D$ is the pile diameter.

Fig. 6 and Fig. 7 show the regression curve of cement consumption versus the square of pile diameter. The empirical formula of cement consumption by the square of pile diameter in gravel and silty sand can be expressed as follows.

The cement consumption of a single pile in gravel and pebble can be calculated as:

$Q=1.924\left(D^{2}+0.287\right)$

The cement consumption of a single pile in silty sand can be calculated as:

$Q=2.007\left(D^{2}+0.159\right)$
The regression curves of $Q$ varying with $D$ and $D^{2}$ are quite accurate, especially with $D^{2}$, and it could provide a direction for the design of cement consumption.

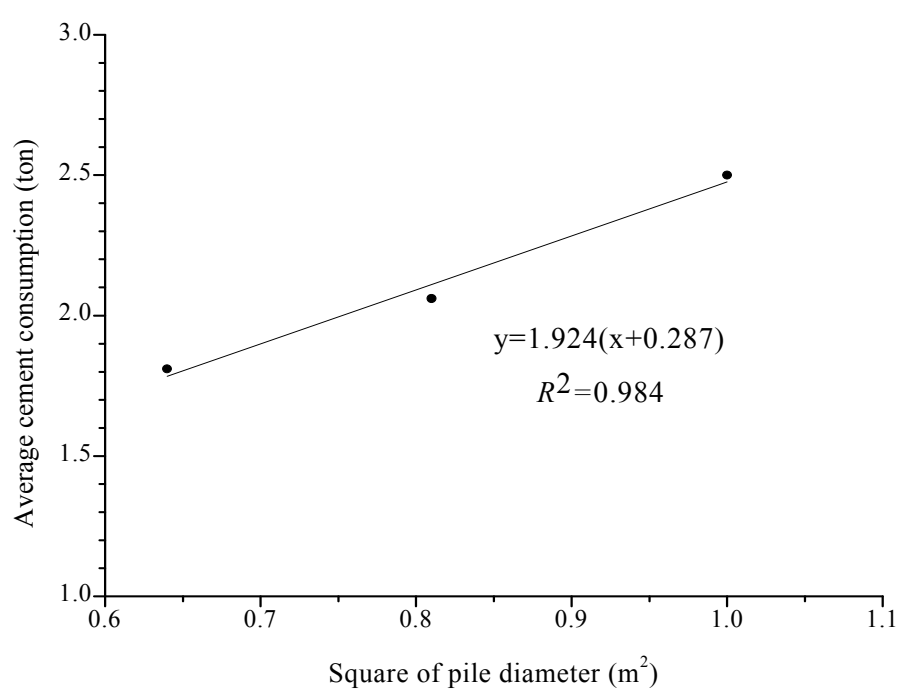

Fig.6 Relationship between cement consumption and the square of pile diameter in gravel and pebble

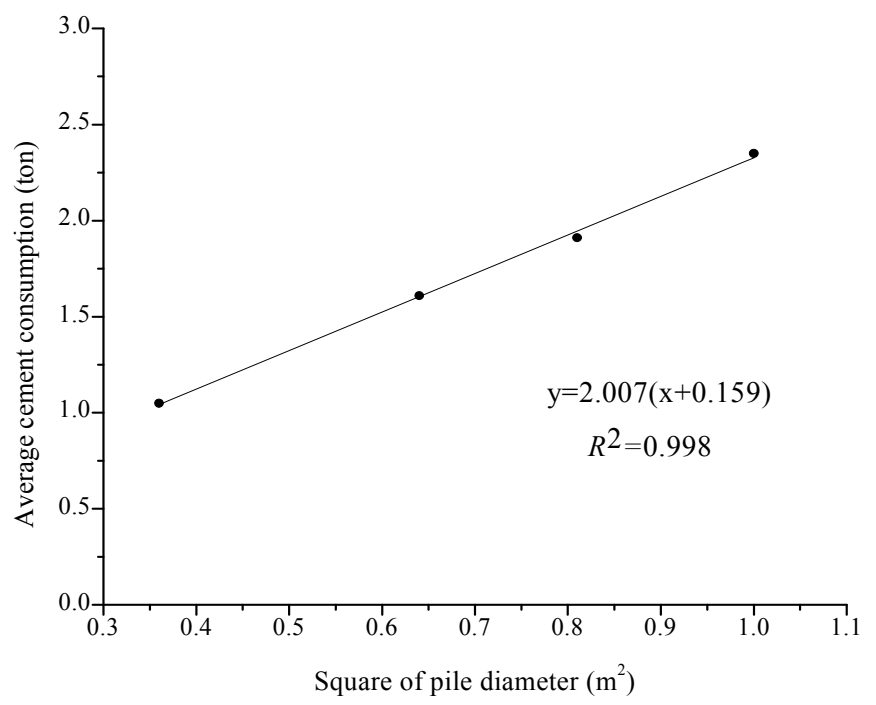

Fig.7 Relationship between cement consumption and the square of pile diameter in silty sand

\section{STATISTICS OF SINGLE-PILE BEARING CAPACITY}

The statistics of single-pile bearing capacities in various bearing layers are listed in Table 5, Table 6, Fig.8 and Fig.9.

It can be indicated from Table 4 that the singlepile bearing capacities in the four bearing layers are all improved after grouting. Enhancement coefficient $\beta$ of post grouting pile's bearing capacity (ultimate bearing capacity of grouted pile to that of conventional pile with the same pile diameter and length in similar ground condition) varies from 1.16 
to 1.81 . Under a given pile diameter, the improvement of bearing capacity in gravel and silty sand is the biggest. As grouting effect is the most significant in the two layers, which is the reason why grouting is always used in those layers.

Table 4 Relationship between enhancement coefficient $\beta$ and pile diameter $D$ in various bearing layers

\begin{tabular}{|c|c|c|c|c|c|c|c|c|}
\hline Pile Diameter & 600 & 700 & 800 & 850 & 900 & 1000 & $\geq 1200$ & Average \\
\hline Bearing Layer & & & & & & & & \\
\hline Silt and clay & 1.51 & & 1.25 & 1.27 & & & 1.39 & 1.35 \\
\hline Silty sand & 1.57 & & 1.38 & 1.31 & 1.48 & 1.49 & 1.18 & 1.40 \\
\hline Gravel and pebble & 1.81 & 1.54 & 1.46 & & 1.53 & 1.61 & 1.54 & 1.54 \\
\hline Bedrock & & 1.53 & 1.29 & & 1.16 & & & 1.32 \\
\hline
\end{tabular}

Table 5 Relationship between enhancement coefficient $\beta$ and pile length $L$ in various bearing layers

\begin{tabular}{|c|c|c|c|c|c|c|c|c|}
\hline $\begin{array}{c}\text { Pile Length } \\
\text { Bearing layer }\end{array}$ & $0 \sim 20$ & $20 \sim 30$ & $30 \sim 40$ & $40 \sim 50$ & $50 \sim 60$ & $60 \sim 70$ & $\geq 70$ & Average \\
\hline Silt and clay & 1.34 & 1.41 & & 1.27 & 1.1 & 1.64 & & 1.35 \\
\hline Silty sand & & & 1.42 & 1.39 & 1.36 & 1.27 & & 1.40 \\
\hline Gravel and pebble & 1.79 & 1.56 & 1.52 & 1.49 & 1.47 & 1.44 & 1.39 & 1.54 \\
\hline Bedrock & & 1.34 & & & 1.31 & & & 1.32 \\
\hline
\end{tabular}

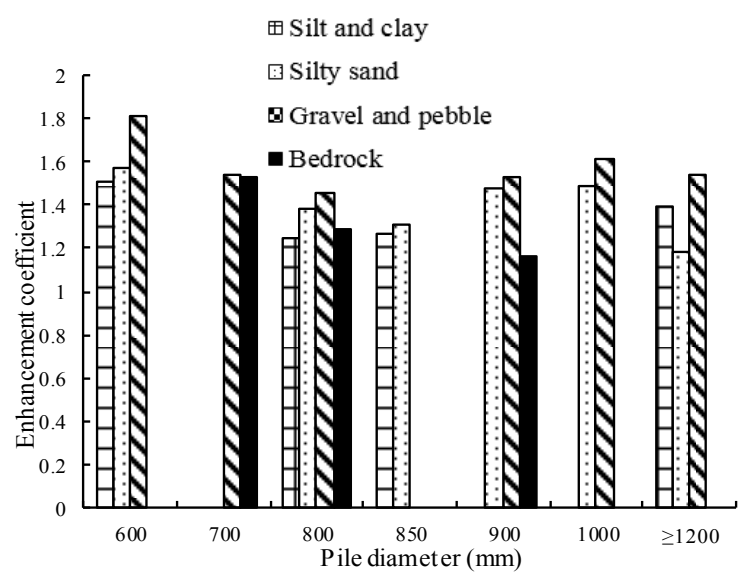

Fig.8 Relationship between enhancement coefficient and pile diameter in various bearing layers

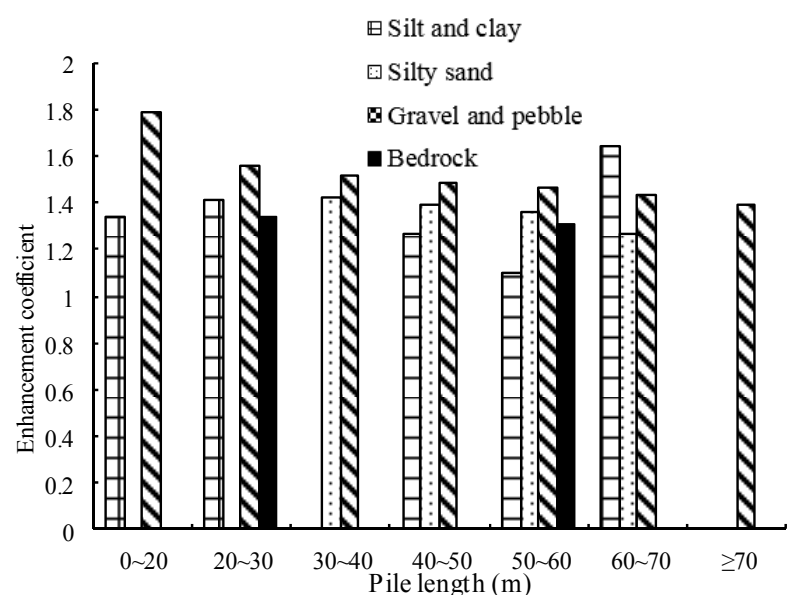

Fig.9 Relationship between enhancement coefficient and pile length in various bearing layers

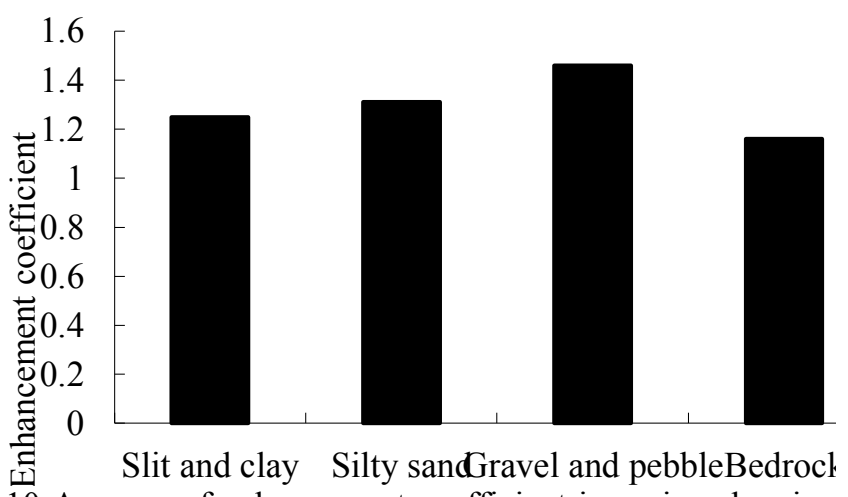

Fig. 10 Average of enhancement coefficient in various bearing layers

Table 5 shows that average enhancement coefficient of post grouting pile's bearing capacity is 1.35 in silt and clay, 1.40 in silty sand, 1.54 in gravel and pebble stratum, and 1.32 in bedrock. The empirical formula of bearing capacity of a single pile with post-grouting is given as follows, where the minimum enhancement coefficient $\beta$ is used for security concern.

$Q_{\mathrm{uk}}=\beta\left(u \sum q_{\mathrm{sik}} l_{i}+q_{\mathrm{p} k} A_{\mathrm{p}}\right)$

Where $Q_{\mathrm{uk}}$ is the ultimate bearing capacity of a single pile with post-grouting; $\beta$ is the enhancement coefficient of single-pile bearing capacity (see Fig.10); $u$ is the perimeter of pile section; $A_{\mathrm{p}}$ is the pile shaft area; $q_{\mathrm{sik}}$ is the unit skin friction; and $q_{\mathrm{p} k}$ is the unit end resistance.

\section{STATISTICS OF PILE DISPLACEMENT}

The statistics of pile displacement in various bearing layers are listed in Fig.11 and Fig. 12. 
Table 6 Statistics of pile displacement in various bearing layers

\begin{tabular}{|c|c|c|c|c|c|c|}
\hline \multirow{2}{*}{ Bearing layer } & \multicolumn{2}{|c|}{$\begin{array}{l}\text { Average pile-head settlement } \\
(\mathrm{mm})\end{array}$} & \multirow{2}{*}{$\begin{array}{l}\text { ratio of pile-head } \\
\text { settlement of grouted } \\
\text { pile to that of con- } \\
\text { ventional pile }\end{array}$} & \multicolumn{2}{|c|}{$\begin{array}{l}\text { Average pile-toe settlement } \\
(\mathrm{mm})\end{array}$} & \multirow{2}{*}{$\begin{array}{l}\text { ratio of pile-toe set- } \\
\text { tlement of grouted } \\
\text { pile to that of con- } \\
\text { ventional pile }\end{array}$} \\
\hline & $\begin{array}{c}\text { Grouted } \\
\text { pile }\end{array}$ & $\begin{array}{c}\text { Conventional } \\
\text { pile }\end{array}$ & & $\begin{array}{c}\text { Grouted } \\
\text { pile }\end{array}$ & $\begin{array}{c}\text { Conventional } \\
\text { pile }\end{array}$ & \\
\hline Silt and clay & 25.4 & 33.5 & 0.76 & & & \\
\hline Silty sand & 24.89 & 36.6 & 0.68 & 5.9 & 15.44 & 0.38 \\
\hline $\begin{array}{l}\text { Gravel and } \\
\text { pebble }\end{array}$ & 20.49 & 30.16 & 0.68 & 3.95 & 17.9 & 0.22 \\
\hline Bedrock & 15.72 & 24.87 & 0.63 & 3.83 & 7.53 & 0.51 \\
\hline
\end{tabular}

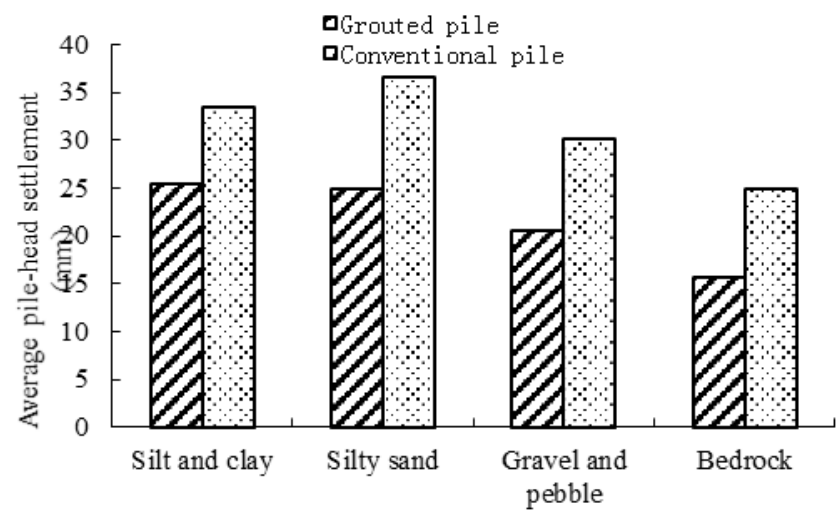

Fig.11 Statistics of pile-head settlements in various bearing layers

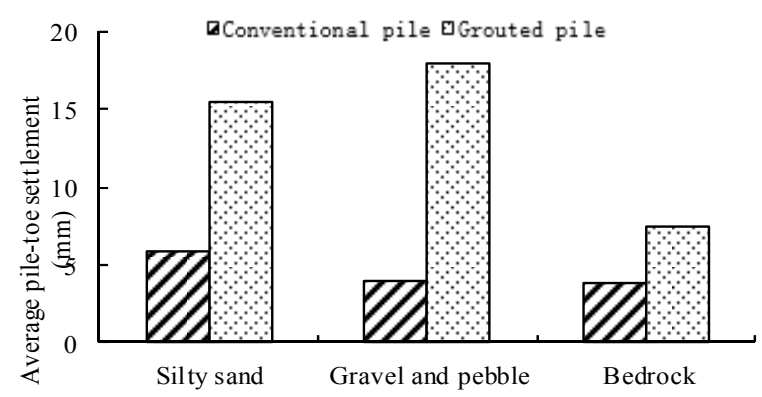

Fig.12 Statistics of pile-toe settlements in various bearing layers

It can be concluded that the pile-head and pile-toe settlements in the four bearing layers are obviously reduced after grouting. The pile-head and pile-toe settlements are reduced by $63 \%$ to $76 \%$ and $22 \%$ to $51 \%$, respectively. Therefore, it is obvious that grouting will notably decrease pile settlement.

\section{CONCLUSION}

Over 600 piles with or without grouting are compared, and the conclusions are given as follows.

(1) Post grouting technique is most used in gravel and pebble stratum (taking up 67.8\%), followed by silty sand (taking up 20.3\%), and it can be used in silt and clay and bedrock as well. When used in bedrock, the main role of grouting is to solidify rock mass and sediment.
(2) By regression analysis of piles in gravel and pebble stratum or silt, the cement consumption is found to be linear with the square of pile diameter.

(3) Enhancement coefficient $\beta$ of post grouting pile's bearing capacity is 1.25 in silt and clay, 1.31 in silty sand, 1.46 in gravel and pebble stratum, and 1.16 in bedrock. For piles with the same diameter, the improvement of bearing capacity in gravel and pebble stratum is the biggest.

(4) By post grouting, the pile-toe settlement can be reduced by $49 \%$ to $78 \%$, and the pile-head settlement can be reduced by $24 \%$ to $37 \%$.

The grouting pipe is pre-placed and grouting is carried out at the end of piling. Therefore, pile-bottom post grouting does not lengthen the construction period or raise the construction cost.

\section{REFERENCES}

Fang, K. \& Zhang Z M. and Zhang Q Q. 2014. Prestressing effect evaluation for a grouted shaft: a case study. Proceedings of the Institution of Civil Engineers-Geotechnical Engineering, 167(3): 253-261.

Kusakabe, O. \& Kakurai, M. and Ueno K. 1994. Structural capacity of precast piles with grouted base. International Journal of Geotechnical Engineering, 120(8): 1289-1306.

Thompson, P A. 1996. Base and shaft grouted piles. Proceedings of the institution of civil engineers: Geotechnical Engineering, 119(3): 186-192.

Vipulanandan, C. \& Krizek, R. 1986. Mechanical behavior of chemically grouted sand. Journal of Geotechnical Engineering, 112(9): 869-887.

Zhang Q Q, \& Zhang Z M. 2012. Complete load transfer behavior of base-grouted bored piles. Journal of Central South University of Technology, 19(7): 2037-2046.

Zhang, Z M. \& Yu, J. and Zhang, G X. 2009. Test study on the characteristics of mudcakes and in situ soils around bored piles. Canadian Geotechnical Journal, 46(3): 241-255. 